\title{
Molecular characterization of human T-cell lymphotropic virus coinfecting human immunodeficiency virus 1 infected patients in the Amazon region of Brazil
}

\author{
RV Laurentino, IGL Lopes, VN Azevedo, LFA Machado, MRC Moreira*, L Lobato**, \\ MOG Ishak, R Ishak, ACR Vallinoto/ ${ }^{+}$
}

\begin{abstract}
Laboratório de Virologia, Departamento de Patologia, Centro de Ciências Biológicas, Universidade Federal do Pará, Rua Augusto Corrêa 1, 66075-900 Belém, PA, Brasil *Laboratório Central do Estado do Amapá, Macapá, AP, Brasil **Unidade de Referência de Doenças Infecciosas e Parasitárias Especiais, Belém, PA, Brasil
\end{abstract}

The present work evaluated the epidemiology of human immunodeficiency virus 1/human T-cell lymphotropic virus (HIV-1/HTLV) coinfection in patients living in Belém (state of Pará) and Macapá (state of Amapá), two cities located in the Amazon region of Brazil. A total of 169 blood samples were collected. The sera were tested by enzymelinked immunosorbent assay to determine the presence of antibodies anti-HTLV-1/2. Confirmation of infection and discrimination of HTLV types and subtypes was performed using a nested polymerase chain reaction targeting the $p X$ and 5' LTR regions, followed by restriction fragment length polymorphism and sequencing analysis. The presence of anti-HTLV1/2 was detected in six patients from Belém. The amplification of the $p X$ region followed by RFLP analysis, demonstrated the presence of HTLV-1 and HTLV-2 infections among two and four patients, respectively. Sequencing HTLV-1 5' LTR indicated that the virus is a member of the Cosmopolitan Group, Transcontinental subgroup. HTLV-2 strains isolated revealed a molecular profile of subtype HTLV-2c. These results are a reflex of the epidemiological features of HIV-1/HTLV-1/2 coinfection in the North region of Brazil, which is distinct from other Brazilian regions, as reported by previous studies.

Key words: human T-cell lymphotropic virus - human immunodeficiency virus 1 - retrovirus - coinfection molecular epidemiology

Human T-cell lymphotropic virus 1 and 2 (HTLV-1 and HTLV-2) are members of Retroviridae family, and share some biological and molecular properties (Hall et al. 1992). HTLV-1 is endemically found in distinct geographic areas, such as Japan, the Caribbean Basin, parts of West Africa, Melanesia, South America, and Middle East (Manns et al. 1999); in these places, the infection is commonly associated with hematological and neurological disorders (Osame et al. 1987, Murphy et al. 1989). HTLV-2 is mainly found among Indians from the Americas and intravenous drug users (IDU) from US, Europe, and Brazil (Hall et al. 1992, Ishak et al. 1995, Switzer et al. 1995, Taylor, 1996, Egan et al. 1999).

In Brazil, there are distinct epidemiological profiles of infection by HTLV (Galvão-Castro et al. 1994). In the Northeast region of the country, HTLV-1 is the most prevalent type (Castro-Costa et al. 1991, Galvão-Castro et al. 1994, Dourado et al. 1999, 2003), while in the North region HTLV2 is considered the most prevalent, and the Amazon region, the geographical area with the highest rate of infection (Ishak et al. 2003). The South region of Brazil has reported infection both by HTLV-1 and HTLV-2 with similar rates (Galvão-Castro et al. 1994).

Financial support: grants from CNPq, Capes, Sectam, Universidade Federal do Pará

+Corresponding author. E-mail: vallinoto@ufpa.br

Received 15 February 2005

Accepted 2 June 2005
The prevalence of HIV-1/HTLV coinfection is supported by similar routes of transmission and it has been widely studied and reported. The implication of coinfection in HIV-1 infection prognosis is unclear until now (Lefrére et al. 1990, Visconti et al. 1993), but it is suggested that in the course of the disease patient can be significantly deprived (Brites et al. 2001). In Brazil, HIV/HTLV coinfection is relatively high and is associated to risk factors that include previous blood transfusion, intravenous drug usage and sexual contact with multiples partners (Brites et al. 1997, Vallinoto et al. 1998).

In the present study we evaluated the prevalence of coinfection and phylogenetic relationship of HTLV-1 and HTLV-2 strains isolated from HIV-1 patients, in order to monitor and characterize the molecular epidemiology of HTLV coinfecting HIV-1 seropositive patients living in the Amazon region of Brazil.

\section{MATERIALS AND METHODS}

Population group examined and sample collection Blood samples were collected from 169 patients infected by HIV-1, 117 patients ( 82 men and 35 women) attended at the Reference Unit for Infectious and Parasitary Diseases (Uredipe) of the state of Pará and 52 (34 men and 18 women) from the Central Laboratory of Public Health of the state of Amapá (Lacen-AP). Blood samples were placed in tubes containing EDTA in order to obtain plasma and peripheral blood mononuclear cells (PBMC). Both specimens were stored at $-20^{\circ} \mathrm{C}$ before use.

Serological assays - Samples were screened for the presence of anti-HTLV-1/2 using enzyme-linked 
immunosorbent assay (HTLV-1/2 Ab-Capture ELISA Test System, Ortho Diagnostic Systems Inc., Raritan, NJ, US). Positive samples were tested in duplicate before confirmation by nested PCR.

Nested PCR and RFLP - DNA extraction was performed on PBMC from HTLV-1/2 serorreactive subjects. Nested PCR and RFLP targeted the amplification of 159 $\mathrm{bp}$ of the $\mathrm{pX}$ region as previously reported (Vallinoto et al. 2002).

All samples characterized as HTLV-1 were subjected to a nested PCR to amplify the 5' LTR region. The external primers sequences were 5'-TGACAATGACCATGA GCCCCAA-3' (LTR-I.01) and 5'-CGCGGAATAGGGCTA GCGCT-3' (LTR-I.02), corresponding to nucleotide positions 1-22 and 823-842, respectively. The internal primers sequences were 5'-GGCTTAGAGCC TCCCAGTGA-3' (LTR-I.03) and 5'-GCCTAGGGAATAAAGGGGCG-3' (LTR-I.04) corresponding to nucleotide positions 30-49 and 781-800 from HTLV-I ${ }^{\text {ATK }}$ strain. The PCR product was electrophoresed on $1.5 \%$ agarose gels $(200 \mathrm{~V}, 120 \mathrm{Amp} / 45$ $\mathrm{min}$ ) and purified by QIA Quick Purification Kit (Qiagen Inc., Maryland, US) prior to direct sequencing of the product.

All samples characterized as HTLV-2 were submitted to a nested PCR to amplify the 5' LTR region, using two sets of primers, 5'-TCGCGATGACAATGGCGACTA GCCTC-3' and 5'-GGGGGCTTTGGGTATTGGAGTTGGG$3^{\prime}$, corresponding to nucleotides 1-26 and 854-831 in the first reaction and $5^{\prime}$-GCCTCCCAAGCCAGCCAC-3' and 5' -GGGAAAGCCCGTGGATTTGCCCCAT-3' in the second reaction, corresponding to nucleotides $16-35$ and 831807 from the HTLV-II ${ }^{\text {MoT }}$ strain. Following the amplification, the LTR fragment was electrophoresed on $1.5 \%$ agarose gels and purified by QIA quick purification kit (Quiagene, US) prior to direct nucleotide sequencing.

Sequencing - The amplified fragments were submitted to a direct sequencing assay according to the protocol of the ABI Prism Dye Terminator Cycle Sequencing Ready Kit (Perkin-Elmer Cetus, Norwalk, California, US); the reaction products were loaded on the ABI Prism 377 DNA Sequencer (Perkin-Elmer Cetus).

Phylogenetic analysis - The nucleotide sequences obtained in the present study originated from the 5' LTR region (Bel10420, AY920498; Bel10564, AY920503; Bel11935, AY920499; Bel10480, AY920500; Bel10562, AY920501; Bel11507, AY920502) were used, together with other HTLV-1 and HTLV-2 strains described in the Genbank, to establish the phylogenetic relationship. The aligned sequences were used in the Phylip 3.56 software package (Felsenstein 1993) to construct Neighbour Joining (NJ) and Maximum Likelihood (ML) trees (using the HKY substitution model). The statistical reliance of the $\mathrm{NJ}$ tree was evaluated using 1000 bootstrap samples. The trees were drawn with the TreeView 1.4 program (Roderic D Page, University of Glasgow, UK).

\section{RESULTS}

Serological analysis - The serological assay detected the presence of antibodies to HTLV-1/2 in six samples
(3.5\%) out of 169 (Table). All the seropositive patients were from Belém, state of Pará. It was not observed serorreactivity among 52 samples from Macapá, state of Amapá.

Molecular characterization and phylogenetic analysis - All samples submitted to PCR had the $\mathrm{pX}$ region amplified. After the RFLP analysis two were typed as HTLV-1 and four were HTLV-2. The phylogenetic analysis of the LTR region resulted in trees with a topology that was identical when using the two different methods, NJ and ML (for NJ tree see Figs 1, 2). Nucleotide sequencing of the $522 \mathrm{nt}$ amplified product from the 5' LTR of HTLV-1, followed by phylogenetic analysis, showed two HTLV-1 strains phylogenetically related to the viral members of the Cosmopolitan group, subgroup Transcontinental (Fig. 1) supported by bootstrap of $89 \%$. The nucleotide sequencing of $517 \mathrm{nt}$ amplified product from the 5' LTR of HTLV-2, after phylogenetic analysis, clustered the samples with other HTLV-2c Brazilian strains (Fig. 2).

TABLE

Serorreactivity to anti-human T-cell lymphotropic virus 1 and 2 among human immunodeficiency virus 1 infected patients living in the states of Pará and Amapá, Brazil

\begin{tabular}{lccccc}
\hline Origin & $\mathrm{N}$ & ELISA & Males $(\%)$ & Females $(\%)$ & Total $(\%)$ \\
\hline Pará & 117 & 6 & $4(66.7)$ & $2(33.3)$ & 5.1 \\
Amapá & 52 & 0 & - & - & 0 \\
\hline Total & 169 & 6 & 4 & 2 & 3.5 \\
\hline
\end{tabular}

\section{DISCUSSION}

In the present study the coinfection HIV/HTLV was confirmed in six patients, residents of Belém, with a higher prevalence of HTLV-2 infection than HTLV-1. These results confirm our previous report (Vallinoto et al. 1998), that shows a higher prevalence of HIV-1/HTLV-2 coinfection in the urban area of Belém, which is different from other studies in Brazil, where a higher prevalence of HIV-1/HTLV-1 coinfection has been observed (Brites et al. 1997). This is probably due to the highest endemicity for HTLV-2 found in the Amazon region of Brazil (Ishak et al. 2001).

The absence of serorreactivity to HTLV-2 among samples from Macapá is at least intriguing. As far as we are aware, this region shows a high degree of miscegenation with Indian populations that inhabit the borders of the state and that have been reported as communities with high prevalence for HTLV-2 infection (Ishak et al. 1995). We are in an initial process of epidemiological study of HTLV infection in the state of Amapá and this preliminary study highlights the need to determine the actual epidemiology of HTLV infection in this area of the Amazon region of Brazil.

In the present study it was detected the presence of HTLV-1, Cosmopolitan Group, Transcontinental subgroup, in two patients coinfected by HIV-1. This is in agreement 


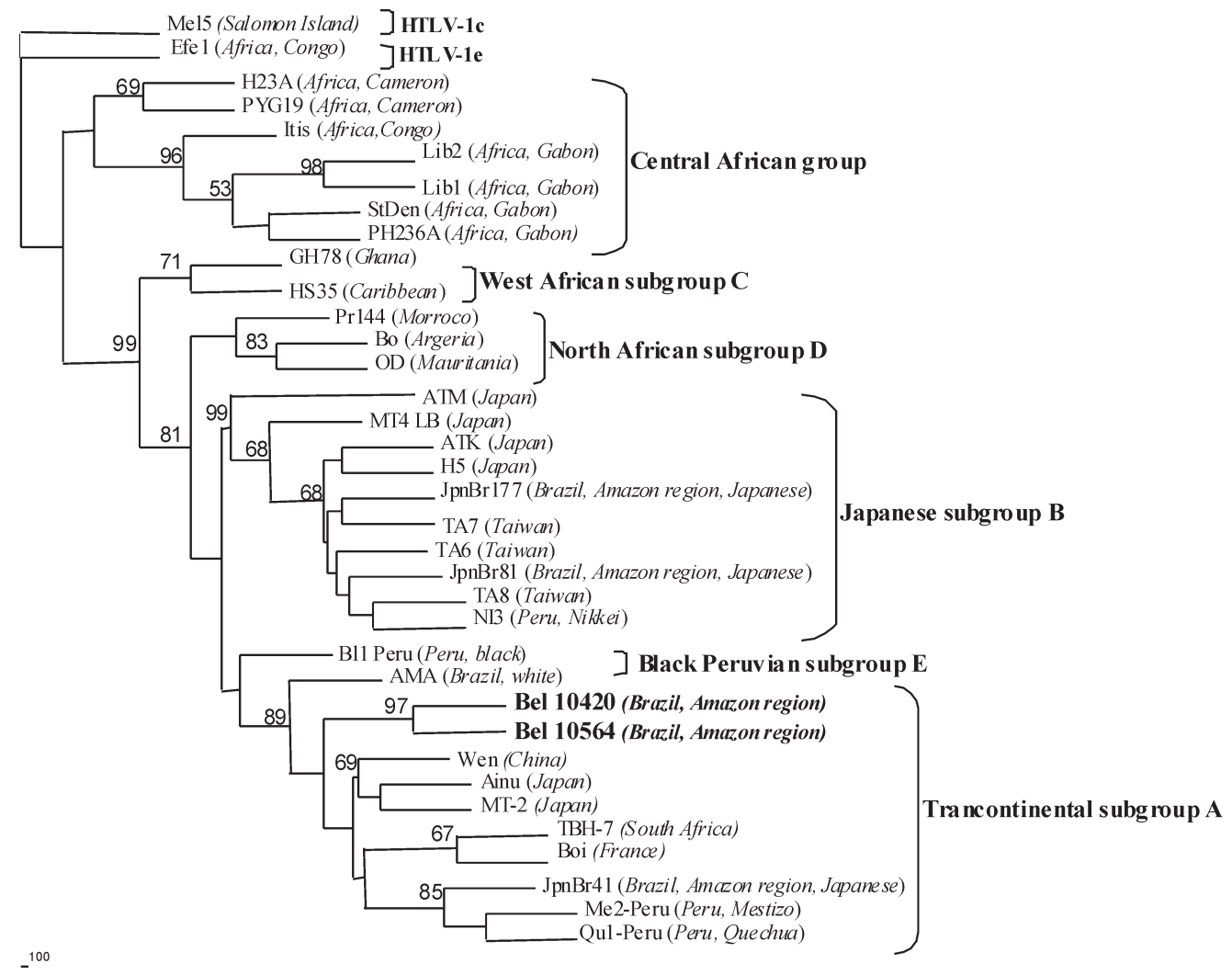

Fig. 1: rooted phylogenetic tree, showing the evolutionary relationship of human T-cell lymphotropic virus 1 strains described thus far including newly sequenced isolates from the present study (Bel-10420 and Bel-10564). The tree was constructed by the Neighbour Joining method after alignment of 522 nucleotides of the 5' LTR region. The Mel5 isolate was used as outgroup. The statistical support was applied using 1000 bootstrap replicates. Cosmopolitan group: Transcontinental (subgroup A), Japanese (subgroup B), West African (subgroup C), North African subgroups (subgroup D), and Black Peruvian (subgroup E). Geographical origin and ethnic origin are given in italics between parentheses.

with other studies that indicate this subtype as the most prevalent in urban populations such as São Paulo and Salvador (Segurado et al. 2002, Alcântara et al. 2003a). In addition, this subtype has been related in other rural communities in the state of Pará (Pontes et al. 2003, Vallinoto et al. 2004).

The origin of HTLV-1, Cosmopolitan Group, Transcontinental subgroup, in the New World is still controversial. Some evolutionary studies suggest that the first introduction of the virus in the continent occurred by the migration of Mongol population through Bering Straits around 40,000 to 10,000 years ago (Miura et al. 1997, Yamashita et al. 1998, Ohkura et al. 1999, Li et al. 1999, Ramirez et al. 2002). Other studies suggest that the virus was brought along with the post-Columbian African slave trade, around 400 years ago, or more recently, due to migrations of HTLV-1 infected Japanese immigrants to Latin America (Vandamme et al. 1994, Van Dooren et al. 1998, Vallinoto et al. 2004). Considering that Transcontinental subtype has been isolated in several ethnic groups, including Africans and their descendents living in Latin America (Van Dooren et al. 1998), and that the HTLV-1 infection is absent or with low prevalence in the native Indian populations from the Amazon region (Ishak et al. 1995, Shindo et al. 2002), the presence of this subgroup in
Belém could be suggested as a recent introduction of the virus in the Amazon region by the Africans who were brought as slaves around the 17th and the 18th centuries. However, our previous study has failed to identify HTLV1 infection in two semi-isolated Afro-Brazilian populations located in the Amazon region of Brazil (Ishak et al. 1995).

The genetic contribution of the populations inhabiting the Brazilian Amazon region indicates a clear trihybrid model in which the contribution of Whites, Indians and Blacks has been estimated about 47, 41, and $12 \%$, respectively. In Belém the Black contribution values was $16 \%$ (Santos \& Guerreiro 1995). Further studies, including a larger number of samples from different places of the Amazon, will be necessary to confirm the above-mentioned hypothesis or even to rule out a possible preColumbian origin for the HTLV-1 in the Amazon region of Brazil.

Studies of HTLV-2 infection in urban and non-urban communities from the Amazon region have shown the occurrence of an unique molecular subtype, designed as HTLV-2c, that is phylogenetically and phenotypically associated to HTLV-2a and HTLV-2b, respectively (Ishak et al. 1995, Eiraku et al. 1996, Vallinoto et al. 2002, Alcântara et al. 2003b). In the present study, the phylogenetic analysis of the nucleotide sequence of the 5' LTR obtained, 


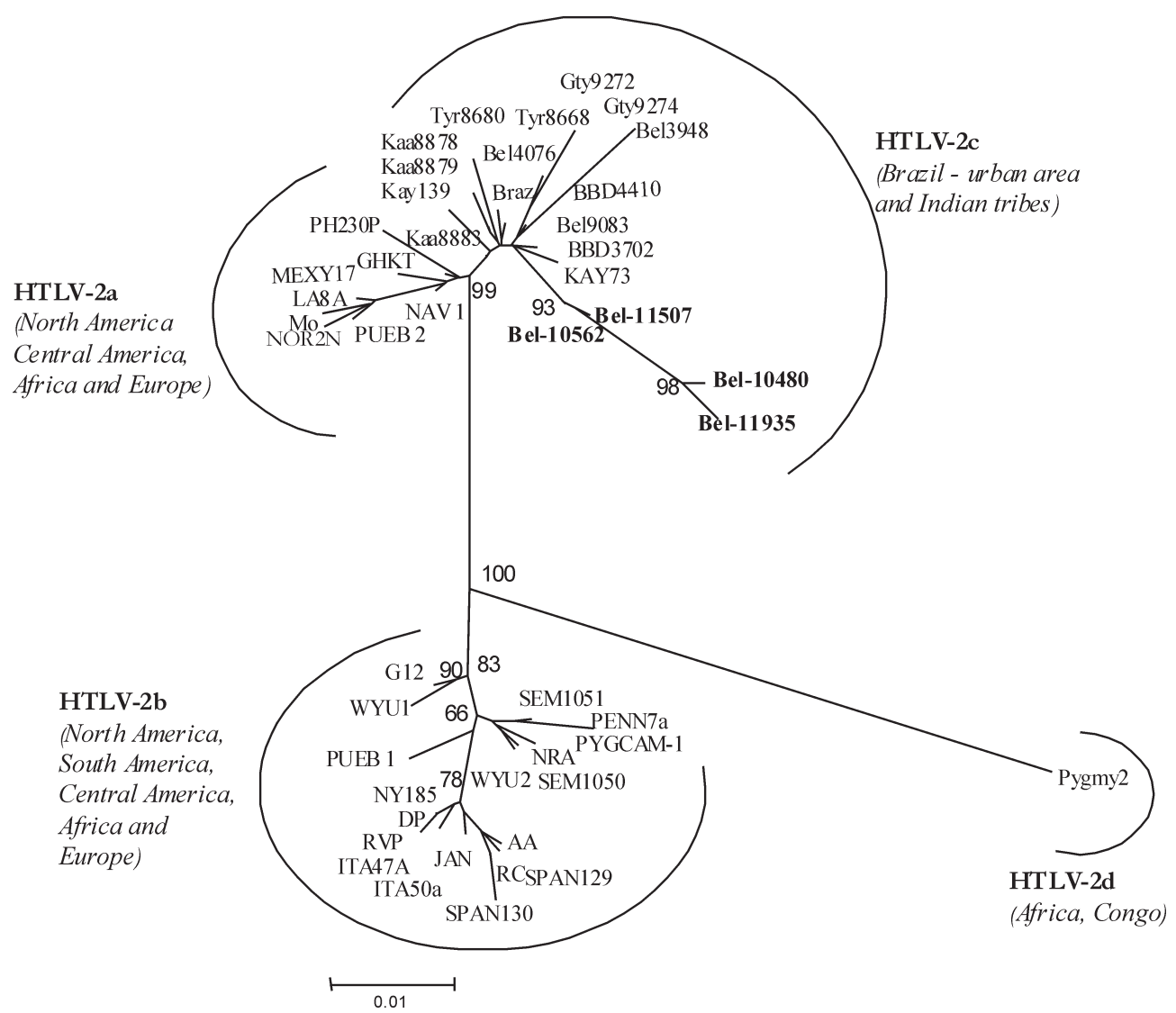

Fig. 2: unrooted phylogenetic tree, showing the evolutionary relationship of human T-cell lymphotropic virus 2 strains described thus far including newly sequenced isolates from the present study (Bel-10480, Bel-10562, Bel-11507, and Bel-11935). The tree was constructed by the Neighbour Joining method after alignment of 517 nucleotides of the 5' LTR region. The statistical support was applied using 1000 bootstrap replicates.

shows that all the four strains isolated clustered in a distinct monophyletic group, associated to HTLV-2a. This result corroborates the proposal of the HTLV-2c as unique molecular subtype found, until now, in the Amazon region of Brazil (Vallinoto et al. 2002).

The evidence, in the present study, of patients presenting the coinfection HIV-1/HTLV-2, highlights the fact that HTLV-2c is expanding its geographical area of endemicity to urban areas, and it is not restricted to the Indian populations of the Amazon region of Brazil, as had been previously reported in other studies (Ishak et al. 1995, Eiraku et al. 1996, Vallinoto et al. 1998, Shindo et al. 2002).

The introduction of HTLV-2 in urban population is still uncertain, once the virus is found endemically among several native Indian tribes in Brazil (Ishak et al. 1995). It has been suggested that HTLV-2c was transmitted and disseminated, in Brazil, by sexual contact during the colonization period (Vallinoto et al. 2002), and was also maintained within the Indian population through vertical transmission and breast feeding (Ishak et al. 1995, Vallinoto et al. 1998). It is possible that the molecular subtype HTLV$2 \mathrm{c}$ was formerly present in the Indian native tribes, with posterior dissemination to the urban populations during its formation, through the inter-ethnic contact during the intense event of miscegenation (Vallinoto et al. 2002).

\section{ACKNOWLEDGMENTS}

To all the patients involved in the present study.

\section{REFERENCES}

Alcântara Jr LC, Shindo N, Van Dooren S, Salami M, Costa MC, Kashima S, Covas DT, Vandamme AM, Galvão-Castro 2003a. Brazilian HTLV type 2a strains from intravenous drug users (IDUs) appear to have originated from two sources: Brazilian Amerindians and European/North American IDUs. AIDS Res Hum Retrov 19: 519-523.

Alcântara Jr LC, Van Dooren S, Gonçalves MS, Kashima S, Cosia MC, Santos FL, Bittencourt AL, Dourado I, Filho AA, Covas DT, Vandamme AM, Galvão-Castro B 2003b. Globin haplotypes of human T-cell lymphotropic virus type I infected individuals in Salvador, Bahia, Brazil, suggest a Post-Columbian African origin of this virus. J Acq Imm Def Synd Hum Retrov 33: 536-542.

Brites C, Alencar R, Gusmão R, Pedroso C, Netto EM, PedralSampaio D, Badaró R 2001. Co-infection with HTLV-1 is associated with a shorter survival time for HIV-1-infected patients in Bahia, Brazil. AIDS 15: 2053-2055.

Brites C, Harrington Jr W, Pedroso C, Netto EM, Badaró R 1997. Epidemiological characteristics of HTLV-I and II coinfection in Brazilian subjects infected by HIV-1. Braz J Inf Dis 1: 42-47. 
Castro-Costa CM, Vale OC, Goubau P, Desmyter J, Carton H 1991. HTLV-I and tropical spastic paraparesis in Fortaleza (Northeastern Brazil). J Trop Geogr Neurol 1: 45-48.

Dourado I, Alcantara Jr LC, Barreto ML, Teixeira MG, GalvãoCastro B 2003. HTLV-I in the general population of Salvador, Brazil: a city with African ethnic and sociodemographic characteristics. J Acquir Immnue Defic Syndr 34: 527-531.

Dourado I, Andrade T, Carpenter CL, Galvão-Castro B 1999. Risk factors for human T-cell lymphotropic virus type I among injecting drug users in Northeast Brazil: Possibly greater efficiency of male to female transmission. Mem Inst Oswaldo Cruz, 94: 13-18.

Egan JF, O'Leary B, Lewis M, Mulcahy F, Sheehy N, Hasegawa H, Fitzpatrick F, O'Connor JJ, O'Riondan J, Hall WW 1999. High rate of human T-lymphotropic virus type IIa infection in HIV type 1 infected intravenous drug abusers in Ireland. AIDS Res Hum Retrov 15: 699-705.

Eiraku N, Novoa P, Ferreira MC, Monken C, Ishak R, Ferreira OC, Zhu SW, Lorenco R, Ishak MOG, Azevedo V, Guerreiro JF, Pombo de Oliveira M, Loureiro P, Hammerschlak N, Ijichi S, Hall WW 1996. Identification and characterization of a new and distinct molecular subtype of human T-cell lymphotropic virus type 2. J Virol 70: 1481-1492.

Felsenstein J 1993. PHYLIP - Phylogeny Inference Package. Version 3.5c. University of Washington, Seattle, US.

Galvão-Castro B, Proietti F, Rodrigues L, Franco F, Santana A, Loures L 1994. HTLV-I/II differential geographic distribution in Brazil. Tenth International Conference on AIDS, Yokohama, Japan.

Hall WW, Takahashi H, Liu C, Kaplan MH, Sheewind O, Ijichi S, Nagashima K, Gallo RC 1992. Multiple isolates and characteristics of human T-cell leukemia virus type II. J Virol 66: 2456-2463.

Ishak R, Harrington Jr W, Azevedo VN, Eiraku N, Ishak MOG, Guerreiro JF, Santos SEB, Kubo T, Monken C, Alexander S, Hall WW 1995. Identification of human T-cell lymphotropic virus type IIa infection in the Kayapo, an Indigenous population of Brazil. AIDS Res Hum Retrovirol 11: 813-821.

Ishak R, Vallinoto ACR, Azevedo VN, Ishak MOG 2003. The epidemiological aspects of retrovirus (HTLV) infections among Indian populations of the Amazon region of Brazil. Cad Saúde Pública 19: 109-118.

Ishak R, Vallinoto ACR, Azevedo VN, Lewis M, Hall WW, Ishak MOG 2001. Molecular evidence of mother to child transmission of HTLV-IIc in the Kararao village in the Amazon region of Brazil. Rev Soc Bras Med Trop 34: 519-525.

Lefrère JJ, Couroucê AM, Mariotti M, Wattel E, Prou O, Bouchardeau F, Lambin P 1990. Rapid progression to AIDS in dual HIV-1/HTLV-I infection. Lancet 336: 509.

Li HC, Fujiyoshi T, Lou H, Yashiki S, Sonoda S, Cartier L, Nunez L, Munoz I, Horai S, Tajima K 1999. The presence of ancient human T-cell lymphotropic virus type I provirus DNA in an ancient Andean mummy. Nature Med 5: 14281432.

Manns A, Hisada M, La Granade L 1999. Human Tlymphotropic virus type I infection. Lancet 353: 19511958.

Miura T, Yamashita M, Zaninovic V, Cartier L, Takehisa J,
Igarashi T, Ido E, Fujiyoshi T, Sonoda S, Tajima K, Hayami M 1997. Molecular Phylogeny of Human T-Cell Leukemia Virus Type I and II of Amerindians in Colombia and Chile. J Mol Evol (Suppl. 1) 44: S76-S82.

Murphy EL, Hanchard B, Figueroa JP, Gibbs WN, Lofters WS, Campbell M, Goedert JJ, Blattner WA 1989. Modelling the risk of adult $\mathrm{T}$ cell lymphoma/leukemia in persons infected with human T lymphotropic virus type I. Int J Cancer 43: 250-253.

Ohkura S, Yamashita M, Cartier L, Tanabe DG, Hayami M, Sonoda S, Tajima K 1999. Identification and phylogenetic characterization of a human T-cell leukaemia virus type I isolate from a native inhabitant (Rapa Nui) of Easter Island. J Gen Virol 80: 1995-2001.

Osame M, Matsumoto M, Usuku K, Izumo S, Ijichi N, Amitani H, Tara M, Igata A 1987. Chronic progressive myelopathy associated with elevated antibodies to human $\mathrm{T}$ lymphotropic virus type I and adult $\mathrm{T}$ cell leukemia like cells. Ann Neurol 21: 117-122.

Pontes GS, Muto NA, Lopes IGL, Azevedo VN, Machado LFA, Ishak MOG, Ishak R, Vallinoto ACR 2003. Seroepidemiology and molecular epidemiology of HTLV infection in rural and urban populations from the Amazon region of Brazil. Virus Rev Res 8(Suppl. 1): 211.

Ramirez E, Cartier L, Villoca C, Fernandez J 2002. Genetic characterization and phylogeny of human T-cell lymphotropic virus type I from Chile. Virus Res 20: 135149.

Santos SEB, Guerreiro JF 1995. The indigenous contribution to the formation of the population of the Brazilian Amazon Region. Rev Bras Genet 18: 311-315.

Segurado ACC, Biasutti C, Zeigler R, Rodrigues C, Damas CD, Jorge MLSG, Machiori PE 2002. Identification of human T-lymphotropic virus type I (HTLV-I) subtypes using restricted fragment length polymorphism in a cohort of asymptomatic carriers and patients with HTLV-I associated myelopathy/tropical spastic paraparesis from São Paulo, Brazil. Mem Inst Oswaldo Cruz 97: 329-333.

Shindo N, Alcântara Jr LC, Van Dooren S, Salemi M, Costa MC, Kashima S, Covas DT, Teva A, Pellegrini M, Brito I, Vandamme AM, Galvão-Castro B 2002. Human retroviruses (HIV and HTLV) in Brazilian Indians: seroepidemiological study and molecular epidemiology of HTLV type 2 isolates. AIDS Res Hum Retroviruses 18: 71-77.

Switzer WM, Pieniazek D, Swanson P, Sandal HH, Soriano V, Khabbaz RF, Kaplan JE, Lal RB, Heneine W 1995. Phylogenetic relationship and geographic distribution of multiple human T-cell lymphotropic virus type II subtypes. J Virol 69: 621-632.

Taylor GP 1996. The epidemiology of HTLV-I in Europe. J Acq Imm Def Syndr Hum Retrovirol 13(Suppl. 1): S8-S14.

Vallinoto ACR, Azevedo VN, Santos DEM, Carniceiro S, Mesquita FCL, Hall WW, Ishak MOG, Ishak R 1998. Serological evidence of HTLV-I and HTLV-II coinfections in HIV-1 positive patients in Belém, state of Pará, Brazil. Mem Inst Oswaldo Cruz 93: 407-409.

Vallinoto ACR, Ishak MOG, Azevedo VN, Vicente ACP, Otsuki K, Hall WW, Ishak R 2002. Molecular epidemiology of human T-lymphotropic virus type II infection in Amerindian 
and urban populations of the Amazon region of Brazil. Hum Biol 74: 633-644.

Vallinoto ACR, Muto NA, Pontes GS, Machado LFA, Azevedo VN, Santos SEB, Santos ÂKCR, Ishak MOG, Ishak R 2004. Serological and Molecular Evidence of HTLV-I Infection among Japanese Immigrants living in the Amazon region of Brazil. Jpn J Infec Dis 57: 156-159.

Vandamme AM, Liu HF, Goubau P, Desmyter J 1994. Primate T-lymphotropic virus type I LTR sequence variation and its phylogenetic analysis: compatibility with an African origin of PTLV-I. Virology 202: 212-223.

Van Dooren S, Gutozo E, Salemi M, Watts D, Audenaert E,
Duwe S, Ellerbrok H, Grassmann R, Hagelberg E, Desmyter J, Vandamme A-M 1998. Evidence for a post-Columbian introduction of human T-cell lymphotropic virus in Latin America. J Virol 79: 2695-2708.

Visconti A, Visconti L, Belloco R, Binkin N, Colucci G, Vernocchi L, Amendola M, Ciaci D 1993. HTLV-II/HIV-1 coinfection and risk for progression to AIDS among intravenous drug users. J Acq Imm Def Syndr Hum Retrovirol 6: 1228-1237.

Yamashita M, Picchio G, Veronesi R, Ohkura S, Bare P, Hayami M 1998. HTLV-Is in Argentina are phylogenetically similar to those of other South American countries, but different from HTLV-I in Africa. J Med Virol 55: 152-160. 